\title{
Risk Factors for Febrile Seizures in Children Aged 6-59 Months in Surabaya, East Java
}

\author{
Febrianto Adi Husodo, ${ }^{1}$ Sitti Radhiah, ${ }^{2}$ Pramita Anindya Nugraheni, ${ }^{2}$ \\ ${ }^{1}$ Faculty of Medicine Universitas Hang Tuah, Indonesia, ${ }^{2}$ Department of Child Health Faculty of \\ Medicine Universitas Hang Tuah/Dr. Ramelan Naval Hospital, Surabaya, Indonesia
}

\section{Abstract}

Background: Febrile seizures are common in children under 5 years of age. Parents are concerned when their children have seizures; therefore, it is necessary to provide promotive and preventive education regarding the risk factors for febrile seizures so that parents are more prepared. This study aimed to explore the risk factors for febrile seizures in children.

Methods: This case-control study was conducted on 170 children. Sampling was carried out by purposive sampling on inpatients and/or outpatients at the Department of Child Health Dr. Ramelan Naval Hospital Surabaya during May 2019-July 2020. Secondary data for children with fever were retrieved from medical records, with seizures $(n=85)$ and without seizures $(n=85)$ as a control group. Furthermore, data on temperature, age, birth weight, and history of asphyxia were analyzed and compared, using the chi-square test or Fisher's exact test.

Results: There was a significant difference between the case and control groups regarding the history of asphyxia and the occurrence of febrile seizures ( $\mathrm{p}=0.002 ; \mathrm{OR}=26.39$; and 95\% CI 1.52-455.62). There was no significant difference between the risk factors for high temperature $(p=0.12)$, age $(p=0.52)$, or birth weight $(\mathrm{p}=0.37)$ with the occurrence of febrile seizures.

Conclusions: A history of asphyxia in children under five years is a risk factor for febrile seizures. Appropriate education from health professionals can help parents improve their knowledge, attitudes, and practices in dealing with febrile seizures and their risk factors.

Keywords: Children aged 6-59 months, febrile seizure, risk factors

\section{Introduction}

Febrile seizures are a common problem in children, frequently encountered in pediatric emergency practice and are the most common cause of seizures in children under five years of age. ${ }^{1,2}$ Parents are often afraid of the occurence of febrile seizures because they think their child would die. ${ }^{3}$ About $66 \%$ of mothers are concerned about febrile seizures and consider febrile seizures to be life-threatening for their children. The mothers believed that the seizures will cause brain damage and paralysis may occur, ${ }^{4}$ indicating the need for promotive and preventive efforts to parents, especially about the risk factors for febrile seizures.

Febrile seizures often occur at the age of 6-60 months with a temperature of $\geq 38^{\circ} \mathrm{C}$. This condition is not due to a central nervous system infection, electrolyte or metabolic disorders, and without a previous history of epilepsy. ${ }^{1,5,6}$ Febrile seizures are divided into two groups, namely simple febrile seizures and complex febrile seizures. ${ }^{3}$ Simple febrile seizures are brief (less than 15 minutes), tonic-clonic, and occur once every 24 hours. $^{3}$ Whereas complex febrile seizures usually show a picture of focal or partial seizures on one-sided or generalized seizures preceded by partial seizures, seizure duration of more than 15 minutes and seizure more than once for 24 hours. $^{3}$ The percentage of febrile seizures in Indonesia was $2-4 \%$ in 2008 and at the age interval of 6 months-7 years, ${ }^{7}$ compared with the percentage of febrile seizures in the United States and Western Europe which is $2-5 \%$ at the age of 6 months- 5 years with a peak incidence at $12-18$ months of age. ${ }^{8}$ Based

Correspondence: Febrianto Adi Husodo, Faculty of Medicine Universitas Hang Tuah, Jalan Gadung No. 1 Komplek Barat RSAL dr. Ramelan, Surabaya, East Java, Indonesia, E-mail: husodo9@gmail.com 
on gender, febrile seizures are more common in males than females, with a ratio of $1.3: 1{ }^{9}$ Risk factors for febrile seizures include fever, age, family history, prenatal history (age at pregnancy), or perinatal history (asphyxia, gestational age, and low birth weight babies). ${ }^{10}$ Several genes are associated with febrile seizures, such as SCN1A, SCN1B, SCN9A, TMEM16, CPA6, and GABGR2. ${ }^{11-13}$ Tonsillitis, upper respiratory tract infection, otitis media, roseola infantum, or Shigella gastroenteritis frequently cause fever and are contributing factor in the incidence of febrile seizures. ${ }^{14}$ Rhinovirus, Adenovirus and Enterovirus are the most common viruses in children with febrile seizures where these viruses are found along with other viruses. ${ }^{15}$ Meanwhile, Influenza and Parainfluenza viruses are most commonly found as a single infection. ${ }^{15}$ Vaccines, blood iron levels, or blood zinc levels are also associated with the occurrence of febrile seizures. ${ }^{8,11,14,15}$

This study aimed to explore the risk of febrile seizures in children under 5 years old. Moreover, the result might be useful for health professionals in promoting and preventing the risk factor related to febrile seizure to the parents.

\section{Methods}

This case-control study was conducted at Dr. Ramelan Naval Hospital Surabaya, by obtaining secondary data from medical records from May 2019-July 2020. The group of children with febrile seizures was compared with the control group without seizures. Inclusion criteria for children with febrile seizures aged 6-59 months with a temperature of $\geq 37.5^{\circ} \mathrm{C}$ (axillary). Exclusion criteria were incomplete medical records, presence of central nervous system infection, metabolic or electrolyte disorders, long-term use of anticonvulsant drugs, presence of tumors in the central nervous system and a history of seizures without previous fever. The inclusion and exclusion criteria for the control group were similar to the case group, except for the seizure. The sample size based on the calculation was 170 subjects, thus 85 cases and 85 controls. Sample selection used the purposive sampling method.

This study was approved by the Health Research Ethics Committee, Dr. Ramelan Naval Hospital Surabaya. Data analysis included descriptive analysis, chi-square hypothesis test, and Fisher's exact hypothesis test. Descriptive analysis showed the frequencies and percentages of the samples. Chi-square showed a significant difference when the author compared the case and control groups with the independent categorical variable. This study used chi-square when the number of samples met with chi-square requirements (no blank cells, no cells with an expected value of less than one, and the number of cells with an expected value of less than five not more than $20 \%$ of all cells). Chi-square with Yate's correction was used for the independent categorical variable in the $2 \times 2$ table and met the chi-square requirements. The independent categorical variables that did not meet the requirements of the chi-square test used Fisher's exact test in the $2 \times 2$ table. The Pearson chi-square used the $4 \times 2$ table for the independent categorical variable and met the requirements of the chi-square test.

Parameter of the strength of the relationship between risk factor variables and febrile seizures was expressed as the odds ratio. Significant value if $\mathrm{p} \leq 0.05$ with a confidence interval of $95 \%$.

\section{Results}

In total, 2341 samples of medical record data were obtained and 182 samples were selected, of which 170 samples were taken according to the sample size calculation. Data on general characteristics of research subjects in the case and control groups showed that the gender in the case and control groups were mostly male both in cases $(65.9 \%)$ and controls $(55.3 \%)$ (Table 1).

Analysis of risk factors for febrile seizure and characteristic variables showed that most of the cases group had a temperature of $\geq 38^{\circ} \mathrm{C}(95.3 \%)$, whereas all children in the control group had a fever. However, there was no significant difference between case and control groups regarding temperature with febrile seizures $(p=0.12)$. Similarly, there was no significant difference between case and control groups regarding birth weight with febrile seizures $(p=0.37)$. Also on age, the results showed no significant difference between case and control groups regarding age with febrile seizures $(p=0.52)$.

Interestingly, there were more children without a history of asphyxia in the control group $(100 \%)$ than in the case group $(87.1 \%)$, indicating that there was a significant difference between the case and control groups regarding the history of asphyxia with febrile seizures $(p=0.002$; odds ratio $=26.39$; and $95 \%$ confidence interval 1.52-455.62) (Table 2). 
Table 1 Clinical Characteristics of Febrile Children with or without Seizure

\begin{tabular}{lcc}
\hline & \multicolumn{2}{c}{ Febrile children } \\
\cline { 2 - 3 } Characteristic & $\begin{array}{l}\text { With seizure } \\
\text { n(\%) }\end{array}$ & $\begin{array}{c}\text { Without } \\
\text { seizure } \\
\text { n(\%) }\end{array}$ \\
\hline Gender & & \\
Male & $56(65.9)$ & $47(55.3)$ \\
Female & $29(34.1)$ & $38(44.7)$ \\
\hline
\end{tabular}

\section{Discussion}

Our study has explored the correlation In this study, we have explored the risk factors related to children with febrile seizures under 5 years of age. Male is more prevalent than the female with a ratio of 1.9:1, similar to the study in Palembang, with $1.3: 1 .^{9}$ Some of the possible risk factors associated with children with febrile seizures in this study does not seem significant. For example, temperature during fever with febrile seizure $(p=0.12)$, indicating that temperature during fever is not a risk factor for febrile seizures, conforming a study in Libya, ${ }^{16}$ although a study in Jaipur, India has shown a significant difference. ${ }^{17}$ Febrile seizures can occur due to the susceptibility of the developing (immature) central nervous system to the effects of fever, so that the neuronal excitability increases which prompt children to develop febrile seizures. Furthermore, febrile seizures may also be influenced by genetic and environmental factors. ${ }^{8,10}$

This study showed that there was no significant difference between the case and control groups regarding birth weight with febrile seizures $(p=0.37)$ and statistically, birth weight was not a risk factor for febrile seizures. A hospital-based research conducted in Semarang ${ }^{10}$ showed a similar results $(p=0.75)$, as well as study in Iran. ${ }^{18}$ Inversely, a case-control study from Tunisia showed a significant difference in mean birth weight $(p=0.023)$ with the case group had a lower mean than the control group $(2960 \pm 780$ grams versus $3300 \pm 820$ gram). ${ }^{19}$ Infants with low birth weight could experience hypoxiaischemia and/or hemorrhage in the brain's ventricles. Moreover, hypoxic ischemia or occurrence of infection early in the child's life could alter neuronal excitability and is associated with susceptibility to future febrile seizure, especially when there is adequate stimulation such as fever. ${ }^{10}$ The insignificant results of this study is probably due to limited data. Further study classifying birth weight into low birth weight $(<2500$ grams), very low birth weight $(<1500$ grams), or extremely low birth weight ( $<1000$ grams) is of great interest.

In this study, there was no significant difference between the case group and the control group regarding age with febrile seizures $(p=0.52)$, similar to a case-control study conducted on Tunisian children $(p=0.15)$, however there was a trend that the cases had a younger age $(21.42 \pm 12.72$ versus

Table 2 Risk Factors Related to Febrile Seizure

\begin{tabular}{|c|c|c|c|c|c|}
\hline \multirow[b]{2}{*}{ Variable } & \multicolumn{2}{|c|}{ Febrile children $(n=85)$} & \multirow[b]{2}{*}{$\mathbf{p}$} & \multirow[b]{2}{*}{ OR $(95 \% \mathrm{CI})$} & \multirow[b]{2}{*}{ Test } \\
\hline & $\begin{array}{c}\text { With seizure } \\
\text { n(\%) }\end{array}$ & $\begin{array}{c}\text { Without seizure } \\
\text { n(\%) }\end{array}$ & & & \\
\hline $\begin{array}{l}\text { Temperature (axillary) } \\
\geq 38^{\circ} \mathrm{C} \\
<38^{\circ} \mathrm{C}\end{array}$ & $\begin{array}{c}81(95.3) \\
4(4.7)\end{array}$ & $\begin{array}{c}85(100) \\
-\end{array}$ & 0.12 & - & Fisher \\
\hline $\begin{array}{l}\text { Birth weight } \\
<2500 \text { gram } \\
\geq 2500 \text { gram }\end{array}$ & $\begin{array}{c}4(4.7) \\
81(95.3)\end{array}$ & $\begin{array}{c}1(1.2) \\
84(98.8)\end{array}$ & 0.37 & - & Fisher \\
\hline $\begin{array}{l}\text { Age } \\
\text { 6-12 months } \\
\text { 13-24 months } \\
\text { 25-36 months } \\
\text { 37-59 months }\end{array}$ & $\begin{array}{c}34(40) \\
24(28.2) \\
17(20) \\
10(11.8)\end{array}$ & $\begin{array}{c}32(37.6) \\
20(23.5) \\
16(18.8) \\
17(20)\end{array}$ & 0.52 & - & Chi-square \\
\hline $\begin{array}{l}\text { History of Asphyxia } \\
\text { Yes } \\
\text { No }\end{array}$ & $\begin{array}{l}11(12.9) \\
74(87.1)\end{array}$ & 85 (100) & 0.002 & $26.39(1.52-455.62)$ & $\begin{array}{l}\text { Yate's } \\
\text { correction }\end{array}$ \\
\hline
\end{tabular}

Note: ${ }^{*} \mathrm{OR}=$ odds ratio; ${ }^{* *} \mathrm{CI}=$ Confidence Interval 
$24.90 \pm 13.90) \cdot{ }^{19}$ Interestingly, another study in Semarang found a significant difference $(p=0.006)$ between age-related groups. ${ }^{10}$ Children under two years of age have a 3.4 times greater risk of febrile seizures than children over two years of age $(\mathrm{OR}=3.40$; CI95\% 1.39-8.30). ${ }^{10}$ In this study, the most cases of febrile seizure were in the age group of 6-12 months, and the percentage of febrile seizure decreased in the case group with increasing age. In another study site in Palembang, $33.5 \%$ of children aged $1-2$ years had febrile seizures. ${ }^{9}$ The vulnerability of the central nervous system (CNS) may cause febrile seizures since the developmental window period of CNS is less than 2 years of age. When the neuronal excitability increases, children may promptly develop febrile seizures which are also influenced by genetic, environmental factors, and the inability of the inhibitory function of neurons. ${ }^{8,10}$ Once again, the insignificance of the results of this study is probably due to data limitations, and the measuring unit of age used in medical records is "years", thus affecting the data distribution in the variable category of this study which used units of "month".

Interestingly, the history of asphyxia is significantly associated with febrile seizures ( $p=0.002$; OR 26.39, 95\% CI 1.52-455.62), which means that children with a history of asphyxia are 26.39 times more likely to develop febrile seizure than children without history of asphyxia. However, the $95 \%$ confidence interval shows a wide confidence interval, which indicates that the sample size is too small with various possible hypotheses and inaccurate estimates. A study of three-yearold children in Fuchu-Tokyo examined 17,044 children, which aimed to detect the cause of exogenous seizures in children. This study found that the frequency of asphyxia neonates was more significant in children with febrile seizures $(p<0.001),{ }^{20}$ suggesting that a history of asphyxia could be a risk factor for a febrile seizure. However, the case-control study in Semarang has found no significant difference between the two groups $(\mathrm{p}=0.09) .{ }^{10}$ The high risk in this study is probably because asphyxia causes hypoxic conditions and epileptogenous lesions, which increase neuronal excitability and/or impair the inhibitory function of neurons. Therefore, these children are more susceptible to febrile seizures when receiving adequate stimulation such as fever. ${ }^{10}$

There are some limitations in this study. The results of our study had only one significant variable, thus, we could not proceed to a multivariate analysis to assess the effect of several risk factors on febrile seizures. Further studies involving more data might have a further overview of the risk factors associated with febrile seizures among children.

The study concludes that temperature, age, or birth weight do not affect the incidence of febrile seizure in children under five years old. However, a history of asphyxia is a risk factor for febrile seizures. Regardless of the results, health professionals should educate the parents well on dealing with the various risk factors that may be related to febrile seizures, as well as inform the parents what medicine they should prepare at home, and when to go or call the doctor or emergency team. Appropriate education will enhance the knowledge, attitudes, and practices of parents in dealing with a febrile seizure and its risk factors.

\section{References}

1. Eskandarifar A, Fatolahpor A, Asadi G, Gaderi I. The risk factors in children with simple and complex febrile seizures: An epidemiological study. Int J Pediatr. 2017;5(6):5137-44.

2. Jarrett OO, Fatunde OJ, Osinusi K, Lagunju IA. Pre-hospital management of febrile seizures in children seen at the university college hospital, ibadan, Nigeria. Ann Ib Postgrad Med. 2012;10(2):6-10.

3. Arief RF. Penatalaksanaan kejang demam. Cermin Dunia Kedokteran-232. 2015;42(9):658-61.

4. Syahida JA, Risan NA, Tarawan VM. Knowledge and attitude on febrile seizure among mothers with under-five children. Althea Medical Journal. 2016;3(4):649-54.

5. Subcommittee ob Febril Seizures. Clinical practice guideline-febrile seizure: guidelines for the neurodiagnostic evaluation of the child with a simple febrile seizure. Pediatrics. 2011;127(2):389-94.

6. Patterson JL, Carapetian SA, Hageman JR, Kelley KR. Febrile seizures. Pediatr Ann. 2013;42(12):249-54.

7. Kakalang JP, Masloman N, Manoppo JICh. Profil kejang demam di Bagian Ilmu Kesehatan Anak RSUP Prof. Dr. R. D. Kandou Manado periode Januari 2014Juni 2016. e-CliniC. 2016;4(2):14396.

8. Leung AKC, Hon KL, Leung TNH. Febrile seizures: an overview. Drugs Context. 2018;7:212536.

9. Nindela R, Dewi MR,Ansori IZ. Karakteristik penderita kejang demam di instalasi rawat 
inap Bagian Anak Rumah Sakit Muhammad Hoesin Palembang. Jurnal Kedokteran dan Kesehatan. 2014;1(1):41-5.

10. Fuadi, Bahtera T, Wijayahadi N. Faktor risiko bangkitan kejang demam pada anak. Sari Pediatri. 2010;12(3):142-9.

11. Einfeld DOS, Pellock JM. Recent research on febrile seizures: a review. J Neurol Neurophysiol. 2013;4(165):19519.

12. Mikati MA, Tchapyjnikov D. Febrile Seizures. In: Kliegman RM, St Geme III JW, Blum NJ, Shah SS, Tasker RC, Wilson KM, editors. Nelson textbook of pediatrics. $21^{\text {st }}$ ed. Philadelphia: Elsevier; 2020. p. 120719.

13. Feenstra B, Pasternak B, Geller F, Carstensen L, Wang $\mathrm{T}$, Huang $\mathrm{F}$, et al. Common variants associated with general and MMR vaccine-related febrile seizures. Nat Genet. 2014;46(12):1274-82.

14. Camfield C, Camfield P, Neville B. Febrile seizures. In: Engel J, Pedley TA, editors. Epilepsy: a comprehensive textbook. 2nd ed. Philadelphia: Lippincott Williams \& Wilkins; 2008. p. 659-65.
15. Francis JR, Richmond P, Robins C, Lindsay K, Levy A, Effler PV, et al. An observational study of febrile seizures: the importance of viral infection and immunization. BMC Pediatr. 2016;16(1):202.

16. Yousif $A B$, Hafez LM, Benkhaial FS. Risk factors for febrile seizures in Benghazi, Libya: a case-control study. Alexandria J Pediatr. 2017;30(2):68-73.

17. Sharawat IK, Singh J, Dawman L, Singh A. Evaluation of risk factors associated with first episode febrile seizure. J Clin Diagn Res. 2016;10(5):SC10-3.

18. Mahyar A, Ayazi P, Fallahi M, Javadi A. Risk Factors of the First Febrile Seizures in Iranian Children. Int J Pediatr. 2010;2010:862897.

19. Yahyaoui $S$, Lammouchi $M$, Yahyaoui $O$, Olfa B, Sonia M, Samir B. Risk factors for febrile seizures in Tunisian children : a case-control study. J Med Surg Pathol. 2018;4(3):1-5.

20. Tsuboi T, Okada S. Exogenous causes of seizures in children: A population study. Acta Neurol Scand. 1985;71(2):107-13. 